\title{
Follicular Dendritic Cells of Lymph Nodes as Human Immunodeficiency Virus/Simian Immunodeficiency Virus Reservoirs and Insights on Cervical Lymph Node
}

\author{
Rajnish S. Dave', Pooja Jain ${ }^{2}$ and Siddappa N. Byrareddy ${ }^{1 *}$ \\ ${ }^{1}$ Department of Pharmacology and Experimental Neuroscience, University of Nebraska Medical Center, Omaha, NE, \\ United States, ${ }^{2}$ Department of Microbiology and Immunology, Institute for Molecular Medicine and Infectious Disease, \\ Drexel University College of Medicine, Philadelphia, PA, United States
}

OPEN ACCESS

Edited by: Vijayakumar Velu, Emory University,

United States

Reviewed by:

Pamela J. Skinner,

University of Minnesota,

United States

Steven Bosigner,

Emory University,

United States

${ }^{*}$ Correspondence:

Siddappa N. Byrareddy sid.byrareddy@unmc.edu

Specialty section:

This article was submitted

to Viral Immunology,

a section of the journal

Frontiers in Immunology

Received: 19 December 2017

Accepted: 03 April 2018

Published: 19 April 2018

Citation:

Dave RS, Jain P and Byrareddy SN (2018) Follicular Dendritic Cells of Lymph Nodes as

Human Immunodeficiency

Virus/Simian Immunodeficiency

Virus Reservoirs and

Insights on Cervical Lymph Node.

Front. Immunol. 9:805.

doi: 10.3389/fimmu.2018.00805
A hallmark feature of follicular dendritic cells (FDCs) within the lymph nodes (LNs) is their ability to retain antigens and virions for a prolonged duration. FDCs in the cervical lymph nodes (CLNs) are particularly relevant in elucidating human immunodeficiency virus (HIV)-1 infection within the cerebrospinal fluid (CSF) draining LNs of the central nervous system. The FDC viral reservoir in both peripheral LN and CLN, like the other HIV reservoirs, contribute to both low-level viremia and viral resurgence upon cessation or failure of combined antiretroviral therapy (CART). Besides prolonged virion retention on FDCs in LNs and CLNs, the suboptimal penetration of CART at these anatomical sites is another factor contributing to establishing and maintaining this viral reservoir. Unlike the FDCs within the peripheral LNs, the CLN FDCs have only recently garnered attention. This interest in CLN FDCs has been driven by detailed characterization of the meningeal lymphatic system. As the CSF drains through the meningeal lymphatics and nasal lymphatics via the cribriform plate, CLN FDCs may acquire HIV after capturing them from T cells, antigen-presenting cells, or cell-free virions. In addition, CD4+ T follicular helper cells within the CLNs are productively infected as a result of acquiring the virus from the FDCs. In this review, we outline the underlying mechanisms of viral accumulation on CLN FDCs and its potential impact on viral resurgence or achieving a cure for HIV infection.

Keywords: cervical lymph nodes, follicular dendritic cells, T follicular helper cells, central nervous system, human immunodeficiency virus, simian immunodeficiency virus, viral reservoirs, combined antiretroviral therapy

\section{INTRODUCTION}

The cervical lymph nodes (CLNs) are a group of lymph nodes (LNs) in the neck region that are located adjacent to the cervical region of the spinal cord and in close proximity to the sternocleidomastoid muscle. Depending on the location of the CLNs, they may be classified as (a) superficial anterior CLNs, (b) superficial posterior CLNs, (c) superior deep CLNs, or (d) inferior deep CLNs. The glymphatics and meningeal lymphatics system is a functional waste pathway in the vertebrate central nervous system (CNS) $(1,2)$. The glymphatics and meningeal lymphatic system connects the CNS with the CLNs (3-10). More importantly, T cells and antigen-presenting cells (APCs) migrate along with the cerebrospinal fluid (CSF) as it drains along the nasal lymphatic path through the cribriform plate and eventually access the CLNs (Figure 1A) (3). Within the LN, there is a 


\section{A Route of CSF drainage to cervical lymph node}

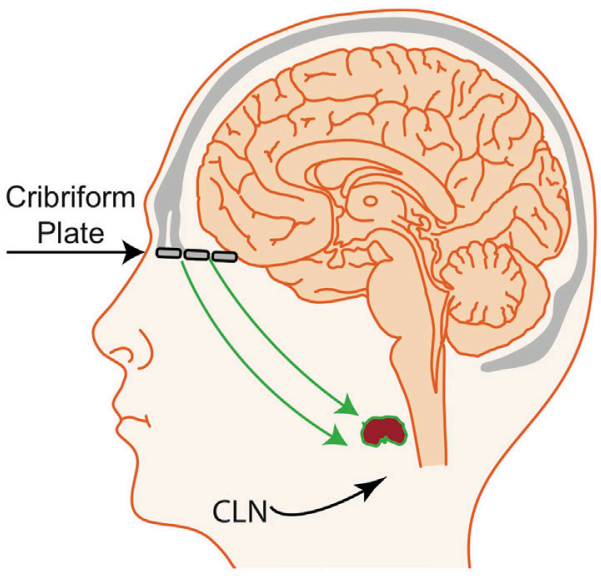

B

GCs \& FDCs in Cervical lymph node

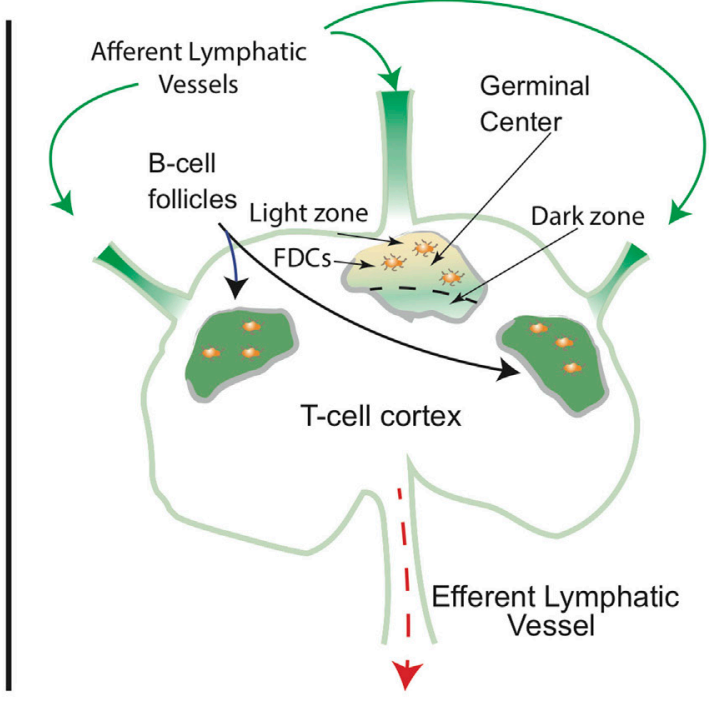

\section{HIV reservoir in Cervical Lymph Node}

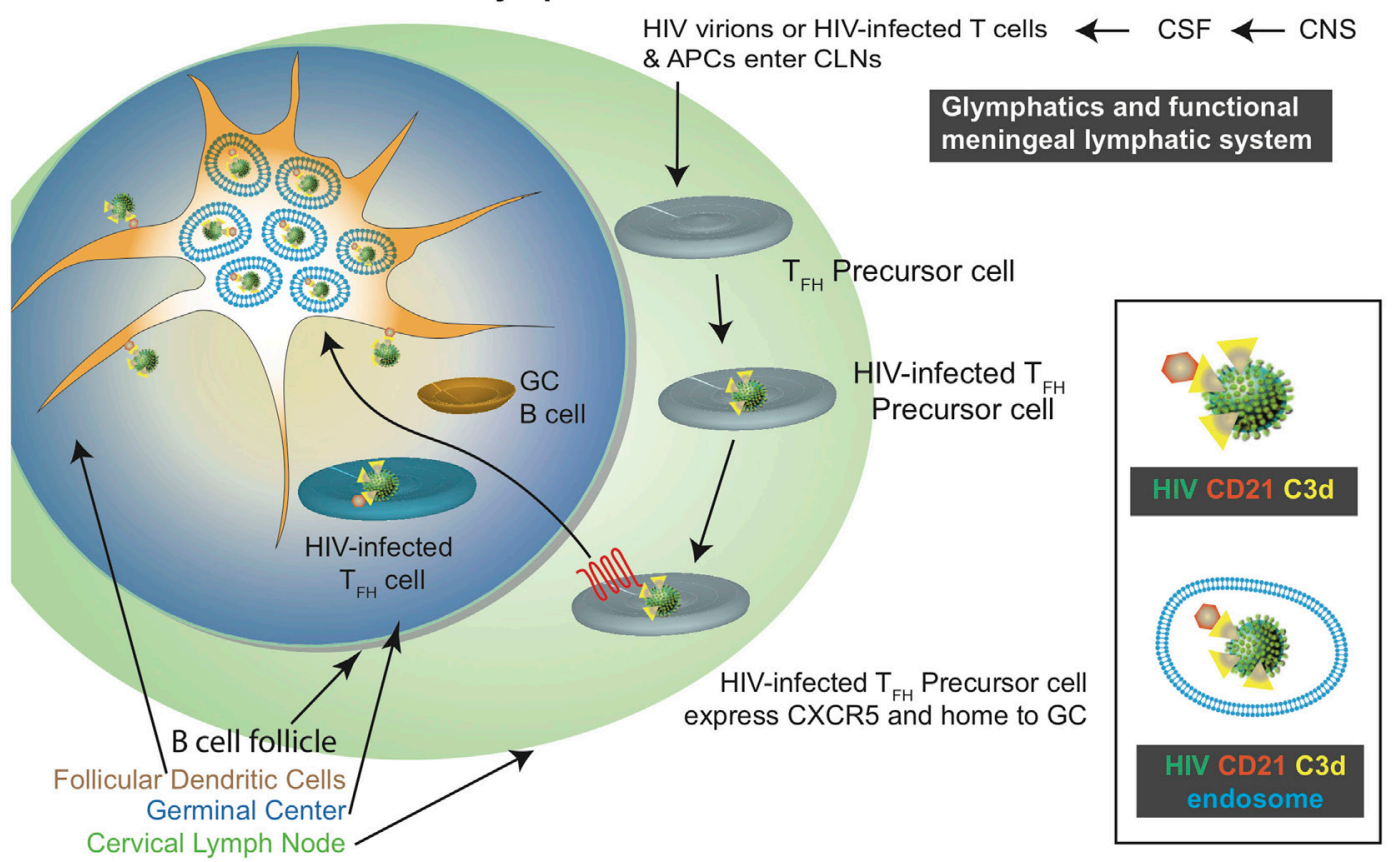

FIGURE 1 | Schematic representation of the central nervous system (CNS)-associated meningeal lymphatic system and the human immunodeficiency virus (HIV) reservoir in the cervical lymph nodes (CLNs). (A) The functional meningeal lymphatic vessels drain cerebrospinal fluid (CSF). T cells and antigen-presenting cells migrate with the CSF along the nasal lymphatic pathways through the cribriform plate to access the CLNs. (B) CSF enters the CLN via the afferent lymphatic vessel and exits through the efferent lymphatic vessels. Germinal center (GC) is located within the B-cell follicle. The follicular dendritic cells (FDCs) are located within the light zone of the GC. (C) Within the CLNs, HIV infects T follicular helper precursor cells, which subsequently express CXCR5 and migrate to the light zone. As depicted in the inset, CD21 interacts with C3d on HIV surface. This interaction results in HIV acquisition by the FDCs. Majority of the FDC associated HIV cycles through the endosomal compartment.

network of stromal cells that includes the follicular dendritic cells (FDCs). FDCs were first identified as "antigen retaining reticular cells" (11). Subsequently, FDCs have been recognized for their unique ability to retain antigens for a prolonged duration (12). This property of FDCs is critical for several immune functions, including germinal center (GC) formation and long-term immune memory. FDCs develop from perivascular precursors of stromal cell origin, which are seeded throughout the body. Their maturation requires lymphotoxin alpha and tumor necrosis factor alpha (TNF-alpha) signaling via B cells (13). FDCs are found within the 
B-cell follicles (BCFs) where GCs develop as a result of a T celldependent antibody response (14). As the BCFs mature within the GCs, FDCs migrate into the light zone (Figure 1B).

Antigen acquisition, processing, and retention by FDCs impact the immune response. FDCs retain antigens for months to years $(15,16)$. However, there is inadequate experimental data demonstrating prolonged antigen retention by FDCs (17). In fact, most predictions are extrapolations based on decay rates. In addition to prolonged antigen retention, FDCs can also similarly retain human immunodeficiency virus (HIV)-1 (Figure 1C) (18). The FDC microenvironment is highly favorable for HIV infection (17). There is evidence in support of combined antiretroviral therapy (cART)-mediated viral clearance (19). Of note, there is a study (20) that conflicts this observation. As such, further investigations are necessary to understand if cART diminishes FDC-associated viral reservoir. Nonetheless, FDCs are considered a lymphoid tissue viral reservoir responsible for residual ongoing viremia (21) as well as, a source of viral resurgence upon cessation of cART (22). Of note, HIV retained by FDCs represents a divergent viral archive (23). The CLN FDCs like FDCs within the peripheral LNs also constitute a HIV/ simian immunodeficiency virus (SIV) reservoir. In this review, we discuss how CLNs acquire, accumulate, and transmit HIV. In addition, we present some recent advances in FDC-related HIV research (Table 1).

\section{CNS AND CLN FDCs ARE IMPORTANT COMPONENTS OF HIV NEURO- IMMUNOPATHOGENESIS}

Human immunodeficiency virus neuroinvasion occurs very early during infection $(41,42)$ with transmigrating infected monocytes/ macrophages (43) and CD4+ T cells (42). In SIV/SHIV macaque models, SIV neuroinvasion occurs within a few days to weeks (44). HIV cannot be eliminated from the CNS as infected monocytes or microglia have a long lifespan and low turnover (45). These monocytes and microglia within the CNS support latent HIV infection (46-49). Since, there is suboptimal penetration of cART $(50,51)$ across the blood-brain barrier (BBB) resulting in establishment of reservoir within the CNS.

Besides the CNS, HIV persists within the LNs, spleen, gutassociated lymphoid tissue, reproductive organs, and lungs $(52,53)$. LNs are a known reservoir of persistent HIV/SIV viral infection under suppressive cART $(34,54-58)$. Several unique characteristics of the LNs contribute to the ability of HIV to persist in this tissue. For example, LN tissue has a slower decay rate than in the peripheral blood (34). Additionally, the LN follicles contain FDCs that capture HIV virions on their cell surface in immune complexes (24). FDCs in the peripheral LNs have also been characterized as another viral reservoir site $(21,35,59)$. Importantly, HIV-susceptible $\mathrm{T}$ follicular helper $\left(\mathrm{T}_{\mathrm{FH}}\right)$ cells are located in close proximity to FDCs, which within peripheral LNs have been shown to trap virions in their native non-degraded state for months to years (60-63) with a half-life of approximately $2-3$ months $(23,64)$. While FDC-trapped virus does not replicate or evolve; however, it can infect nearby trafficking cells $(23,24)$.
TABLE 1 | Advances in follicular dendritic cell (FDC)-related human immunodeficiency virus (HIV) research.

\begin{tabular}{|c|c|}
\hline Major findings & Reference \\
\hline $\begin{array}{l}\text { 1. Simian immunodeficiency virus (SIV) accumulation in rhesus } \\
\text { macaque cervical lymph node (CLN) FDCs and transmission } \\
\text { to } T \text { follicular helper }\left(T_{F H}\right)\end{array}$ & (24) \\
\hline $\begin{array}{l}\text { 2. Enrichment of SIV DNA in CTLA-4 + PD-1-memory cells in } \\
\text { lymph nodes }\end{array}$ & $(25)$ \\
\hline $\begin{array}{l}\text { 3. Engineering unselected CD8 T cells to express CXCR5 directs } \\
\text { them into viral sanctuaries }\end{array}$ & $(26)$ \\
\hline $\begin{array}{l}\text { 4. Identification of a specialized group of CXCR5 expressing } \\
\text { cytotoxic T cells that selectively entered B cell follicles and } \\
\text { eradicated infected } T_{F H} \text { cells and B cells }\end{array}$ & $(27)$ \\
\hline 5. $\mathrm{T}_{\mathrm{FH}}$ are a source of replication competent HIV during latency & $(28)$ \\
\hline $\begin{array}{l}\text { 6. HIV-exposed FDCs show an increased production of } \\
\text { inflammatory cytokines }\end{array}$ & $(29)$ \\
\hline $\begin{array}{l}\text { 7. RNAscope- and DNAscope-based characterization of HIV/SIV } \\
\text { lymphoid reservoir }\end{array}$ & $(30)$ \\
\hline $\begin{array}{l}\text { 8. Combined antiretroviral therapy (cART) interruption results in } \\
\text { widespread resurgence of rebounding/founder HIV variants }\end{array}$ & $(22)$ \\
\hline $\begin{array}{l}\text { 9. Productive SIV infection is restricted to CD4 + TFH cells in } \\
\text { Elite controller macaques and not typical progressors }\end{array}$ & $(31)$ \\
\hline 10. Trafficking of conventional DCs into germinal center (GC) of CLNs & $(32)$ \\
\hline 11. SIV-infected $G C T_{F H}$ derived from $T_{F H}$ precursor cell subsets & (33) \\
\hline $\begin{array}{l}\text { 12. Persistent viral replication in lymphoid tissue due to suboptimal } \\
\text { drug penetration }\end{array}$ & $(34)$ \\
\hline 13. FDCs as a source of low-level viremia & $(21)$ \\
\hline $\begin{array}{l}\text { 14. FDCs increase HIV transcription and production by a soluble } \\
\text { tumor necrosis factor-alpha-mediated mechanism }\end{array}$ & $(35)$ \\
\hline $\begin{array}{l}\text { 15. FDC-trapped virus was replication competent and } \\
\text { demonstrated greater genetic diversity than that of virus } \\
\text { found in most other tissues and cells }\end{array}$ & (23) \\
\hline 16. Anti-CD21 mABs decreases HIV trapping by lymph node cells & $(36)$ \\
\hline $\begin{array}{l}\text { 17. Species-specific colocalization of osteopontin with the } \\
\text { FDC network in lymphatic tissues in HIV-1 and simian } \\
\text { immunodeficiency virus infections }\end{array}$ & $(37)$ \\
\hline $\begin{array}{l}\text { 18. FDC-virus interactions stabilize the virus particle, thus } \\
\text { contributing to the maintenance of infectivity }\end{array}$ & $(38)$ \\
\hline $\begin{array}{l}\text { 19. FDCs serve as a reservoir of infectious virus and render } \\
\text { surrounding GC T cells highly susceptible to infection with } \\
\text { X4 isolates of HIV-1 }\end{array}$ & (39) \\
\hline 20. FDC microenvironment is highly conducive to active HIV infection & $(17)$ \\
\hline $\begin{array}{l}\text { 21. FDC-associated virus accumulates soon after infection and } \\
\text { CART does not diminish the FDC HIV reservoir }\end{array}$ & (20) \\
\hline 22. HIV-1 binds to B cells with CD21 receptor & $(40)$ \\
\hline 23. FDCs accumulate HIV for a prolonged duration & $(18)$ \\
\hline $\begin{array}{l}\text { 24. FDCs-associated HIV is rapidly cleared with potent } \\
\text { antiretroviral therapy }\end{array}$ & (19) \\
\hline
\end{tabular}

Even during cART, replicating virus persists and replenishes trapped stores of $\operatorname{HIV}(22,54)$.

Until the description of glymphatics and the functional meningeal lymphatic system, CNS was considered to be immuneprivileged (5). With the elucidation of structural and functional features of this CNS-associated lymphatic system $(2,3,6)$, it is now 
well established that the CNS undergoes constant immune surveillance in the meningeal compartment. The meningeal lymphatic system, along with glymphatics presents a unique connection between the CNS and CLNs. HIV may pass with CSF as virions, infected T cells, or APCs through the cribriform plate along the nasal lymphatic pathway and access the CLNs. Lymph entering the CLNs through the afferent lymphatics is channeled through the subscapular sinus into the medulla. The fibroblastic reticular cell (FRC) conduits access afferent lymph and traverse BCFs, where they intersect FDCs. FRC conduits continue into the cortex where they end at high endothelial vessels or the medulla (65).

Recent focus directed at better understanding of the meningeal lymphatic system has tremendously enhanced our understanding of immune surveillance in the CNS (2-9). Lymphatic vessels were first identified in the dura mater of rats (7). In some studies of the meningeal lymphatics (3), the system has been described as part of the CNS, while others have drawn opposing conclusions (9). This is not surprising since lymphatic vessels are component of the surrounding connective tissue that is included in the CNS. However, lymphatic vessels can absorb CSF from adjacent subarachnoid space and brain interstitial fluid via the glymphatics. Further detailed investigations are required to fully understand the functionality of CSF drainage, and how it might impact HIV accumulation within CLNs (1).

Circulating conventional DCs (cDCs) are known to traffic into the CNS in response to neuroinflammation (66-73) during HIV/SIV infection (74). Within CNS, cDCs act as both "carrier and bearer" of HIV and contribute both to neuropathology as well as CNS reservoir. Recent studies suggest that cDCs may capture HIV within the CNS and deliver it to different compartments of CLNs including FDCs $(32,60,61,75)$. The CLN FDCs would create a viral repository where virus can remain bound for prolonged duration (63). The immune cell retrograde transport studies $(3,6,76,77)$ provide clues that cDCs upon encountering HIV virions within the brain would migrate along the meningeal lymphatic vessels to draining LNs (CLNs, near the brain stem) via glymphatics delivering HIV particles to different CLN compartments including FDCs as shown for peripheral LNs $(60,61,75)$. However, CLNs are the major site for systemic activation of CNS-specific $\mathrm{T}$ cells. They receive input from the CNS in the form of antigens and cDCs (78). Within CLNs, HIV viral particles may be transmitted to CD4+ $\mathrm{T}$ cells or trapped on the FDC network, thereby stabilizing and protecting HIV and creating a long-term reservoir of infectious HIV $(21,34,38,54)$. In addition, FDCs activate CD4+ T cells within GCs and increase virus production in these cells even in the presence of cART $(35,39,79-81)$. Assessing the involvement of CLNs in HIV neuropathogenesis is timely, given our recent advances in understanding of the functional meningeal lymphatic system (3). Of note, additional mechanistic studies are required to determine if the CLN FDC reservoir is an archive of CNS egressing virus.

\section{KEY CELLULAR PLAYERS IN THE CLN}

Cervical lymph nodes like other LNs play a central role in the development of adaptive immunity against pathogens and, particularly, the generation of antigen-specific B cell responses in specialized areas within GCs (82). Very early in the HIV epidemic, LN pathology was recognized as an important consequence of HIV infection since the beginning of the epidemic. Studies focused on lymphoid tissue architecture during HIV/SIV infection have highlighted the key role of the LN in the disease pathogenesis. The LN environment is unique for viral evolution, primarily because of the relative exclusion of HIV-specific CD8 $\mathrm{T}$ cells (83). In a subsequent study, SIV-specific CD8 T cells in GC and non-GC regions were quantitated (84). Therefore, further investigations are necessary to understand the biology of immune cells in HIV-infected LNs and their critical role in achieving complete viral eradication.

Follicular dendritic cells are a subset of DCs that are of mesenchymal origin and essential for GC formation and production of various types of antibodies (16). They reside in secondary lymphoid tissues such as spleen, tonsils, LNs, and follicles that appear at extranodal sites (85). GCs of secondary lymphoid tissues are composed of several types of immune cells, such as activated $\mathrm{B}$ cells, $\mathrm{T}_{\mathrm{FH}}$ cells, and FDCs. FDCs interact with their GC counterparts. In the GC microenvironment, activated $\mathrm{B}$ cells communicate with FDCs by interacting with an antigen on their surface and then present this antigen to $\mathrm{T}_{\mathrm{FH}}$ cells. FDCs can select for B cells to re-enter the GC or exit with the help of $\mathrm{T}_{\mathrm{FH}}$ cells (15). FDCs have a unique ability to retain immune complexes on their dendritic processes. These immune complexes consist of antigen-antibody complexes and complement (86), which can retain infectious virions for several months even in the presence of neutralizing antibodies or under cART (54). FDCs interact with $\mathrm{T}_{\mathrm{FH}}$ cells in GCs, and these cells serve as a reservoir of infectious virus. Surrounding GC, T cells become highly susceptible to infection with HIV X4 isolates (39). HIV production increases to twofold when viral particles are transferred from FDCs to susceptible CD4+ T cells (35). FDCs can secrete inflammatory cytokines (29) including TNF alpha and thereby contribute to enhanced transcription in the LNs (35).

The underlying mechanisms of HIV/SIV FDC reservoirs remain unclear and require further studies. FDC trapped HIV virions in human lymphoid tissues remain infectious (56). In murine FDCs, HIV virions in immune complexes remained infectious ex vivo for up to 9 months after being captured by FDCs (54). This characteristic of the FDCs is particularly interesting because most of the identified reservoirs of persistent virus are found in the integrated pro-viral stage of the HIV replication cycle. It is important to note that current approaches to eliminate persistent HIV have largely focused on elimination of HIV pro-viral DNA. The HIV/SIV lymphoid reservoir has been well characterized utilizing RNAscope and DNAscope methodologies (30). However, the CLN FDC HIV reservoir has only recently been partially characterized (24) and requires detailed investigation (Table 1).

$\mathrm{T}$ follicular helper are a subset of CD4 T lymphocytes (87) that play a key role in B-cell differentiation. $\mathrm{T}_{\mathrm{FH}}$ cells assist $\mathrm{B}$ cells in the production of antigen-specific antibodies and are essential for memory B cell activation, survival, and differentiation. Even under conditions of durable control, such as in elite controller 
macaques, $\mathrm{T}_{\mathrm{FH}}$ cells contribute significantly to ongoing viral replication and production, and are the single CD4 subset in the LN's most highly enriched in SIV (31). During HIV infection, cellular interactions between FDCs, GC B-cells, and $\mathrm{T}_{\mathrm{FH}}$ cells result in reservoir establishment. $\mathrm{T}_{\mathrm{FH}}$-associated replication competent virus may be the source of resurgent HIV after cART interruption or failure. As such, $\mathrm{T}_{\mathrm{FH}}$ are increasingly recognized as another major CLN-associated reservoir of HIV infection (88-90). However, mechanisms by which these cells get infected remain unclear. $\mathrm{T}_{\mathrm{FH}}$ express very little CCR5 and in macaque studies, it has been shown that $\mathrm{T}_{\mathrm{FH}}$ lacking CCR5 cells can be infected in vivo with CCR5-tropic $\operatorname{SIV}(91,92)$. Infection of the $\mathrm{T}_{\mathrm{FH}}$ population by CCR-5 tropic viruses appears to be the result of infection of the pre- $\mathrm{T}_{\mathrm{FH}}$ cells that express CCR-5 (93).

In cART-naïve as well as treated individuals, $\mathrm{T}_{\mathrm{FH}}$ and $\mathrm{GC}$ $\mathrm{B}$ cells are elevated (94). In addition, there is a direct correlation of $\mathrm{T}_{\mathrm{FH}}$ and GC B cells with the activated T-cell population in the LNs (95). In absence of cART, during chronic HIV infection, viral replication is concentrated in secondary lymphoid follicles (SLF). $\mathrm{T}_{\mathrm{FH}}$ cells have been shown to be highly permissive to HIV within SLF and are the source of replication competent HIV during latency (28). HIV vaccines are not strong inducers of neutralizing antibodies. However, in one of the recently described study, rhesus macaques were immunized with HIV envelope glycoprotein trimer, and there was a substantial production of HIV neutralizing antibodies (96). The high antibody titers had a strong correlation to GC B cells and $\mathrm{T}_{\mathrm{FH}}(96)$. These observations underscore the need to study more details of LNs, since previous HIV reservoir studies have frequently focused primarily on the peripheral blood.

Follicular regulatory $\mathrm{T}$ (TFR) cells are another subset of $\mathrm{T}$ cells in SLF $(97,98)$. TFR share some phenotypic characteristics with the $\mathrm{T}_{\mathrm{FH}}$ cells. Importantly, both $\mathrm{T}_{\mathrm{FH}}$ and $\mathrm{TFR}$ are permissive to HIV infection (99). However, TFR express greater levels of CCR5 and $\mathrm{CD} 4$ as compared with the $\mathrm{T}_{\mathrm{FH}}$ cells. They also support higher frequency of viral replication. Expression of Ki67, a marker of proliferative capacity appears to correlate with viral replication in these cells. As such, TFR differ from $\mathrm{T}_{\mathrm{FH}}$ in their susceptibility to R5 HIV infection (99). Furthermore, it has recently been shown that natural killer (NK) cells migrate into the follicles of secondary LNs. The role of NK cells in LNs is not clear. However, a particular study in African green monkeys demonstrated that entry and persistence of NK cells in LNs was IL-15 dependent, as depletion of IL-15 resulted in an increase in viral replication. These data suggest a key role for NK cells in the establishment and maintenance of this viral reservoir (100).

\section{ERADICATION OF FDC VIRAL RESERVOIR}

A significant challenge to HIV eradication is the elimination of viral reservoirs in GC $\mathrm{T}_{\mathrm{FH}}$ cells. GCs are considered to represent an immune privileged site within the LN where antiviral CD8+ $\mathrm{T}$ cells are primarily excluded $(83,84)$. However, unselected CD8+ T cells engineered to express CXCR5 (C-X-C chemokine receptor type 5, a chemokine receptor required for homing to GCs) direct them to GCs (26). CXCR5 expressing cytotoxic $\mathrm{T}$ cells are able to selectively enter BCFs and eradicate infected
$\mathrm{T}_{\mathrm{FH}}$ and $\mathrm{B}$ cells (27). A population of SIV-specific CD8+ T cells expressed CXCR5 and expanded in LNs following pathogenic SIV infection in a cohort of vaccinated macaques (101). Animals that exhibited greater control of SIV replication had a greater expansion of these cells. The increase in CXCR5+ CD8 $\mathrm{T}$ cells was associated with the presence of higher frequencies of SIV-specific CD8 T cells in the GC (101). Thus, CXCR5+ CD8 $\mathrm{T}$ cells represent a unique subset of antiviral CD8 $+\mathrm{T}$ cells that expand in LNs during chronic SIV infection and may play a significant role in the control of pathogenic SIV infection (101) (Table 1).

An important milestone in purging the FDC reservoir was demonstrated by utilization of soluble complement receptor 2 or CD21 (102). CD21 is necessary for HIV interaction with FDCs and B-cells (40) as interaction of HIV with FDC stabilizes the virus (38). Despite the stabilized interaction, Heesters and co-workers were able to purge the FDCs of HIV virions by utilizing a soluble form of CD21 (102). Thus, intersecting CD21:C3d interactions significantly reduced recycling of virions through the endosomal compartment. In addition, viral transmission to $\mathrm{T}_{\mathrm{FH}}$ was diminished in in vitro studies (102). In an alternate approach to purge FDC HIV reservoir, monoclonal antibodies targeting CD21 were utilized (36). Thus, blocking CD21 interactions appears to be a potential strategy for purging the FDC HIV reservoir.

\section{FUTURE PERSPECTIVES}

Profound and durable suppression of HIV by cART represents a major accomplishment in HIV/AIDS research $(103,104)$. However, HIV persists in patients despite long-term administration of cART (55). Withdrawing cART invariably results in viral rebound $(105,106)$. One of the major challenges with cART is to maintain virologic control. Two types of research strategies have been utilized in HIV cure research. Eradication of replication-competent HIV is considered as a "classic cure" and the best example is Timothy Brown, also known as the Berlin patient (107). Timothy Brown received a stem cell transplant from a donor that was homozygous for delta32 mutation in the CCR5 gene (107). On the other hand, in a "functional cure," viral rebound after cessation of cART is controlled without eradication of HIV. Such functional cure was demonstrated in SIV-infected rhesus macaques with $\alpha 4 \beta 7$ monoclonal antibody (108). Even after cART withdrawal, sustained virologic control was maintained with passive administration of $\alpha 4 \beta 7$ monoclonal antibody (108). However, mechanisms underlying this sustained virologic suppression remain to be elucidated. Other HIV cure strategies include (a) latency-reversing agents (e.g., anti-CD3, Bryostatin, IL-7, Romidepsin, TLR-7 agonists, Valproic acid), (b) immunotoxic therapy with bi-functional antibodies, and (c) precise excision of HIV genomes by CRISPR/Cas9 gene editing in mice (109-111). It needs to be determined if such cure strategies can successfully purge the CNS and the LN HIV reservoirs based on our current understanding of the functional meningeal system, CSF outflow (1), and viral acquisition by FDCs (Figures 1A-C) (24). Lifetime cART is associated with toxicity, residual chronic inflammation, and the accelerated onset of comorbidities associated with aging. Therefore, optimizing other cure strategies 
in combination with cART will be critical to reducing cARTassociated complications and the overall viral burden.

\section{AUTHOR CONTRIBUTIONS}

RD: wrote the review article. PJ and SB: edited the review article.

\section{REFERENCES}

1. Dave RS, Jain P, Byrareddy SN. Functional meningeal lymphatics and cerebrospinal fluid outflow. J Neuroimmune Pharmacol (2018). doi:10.1007/ s11481-018-9778-5

2. Ma Q, Ineichen BV, Detmar M, Proulx ST. Outflow of cerebrospinal fluid is predominantly through lymphatic vessels and is reduced in aged mice. Nat Commun (2017) 8:1434. doi:10.1038/s41467-017-01484-6

3. Louveau A, Smirnov I, Keyes TJ, Eccles JD, Rouhani SJ, Peske JD, et al. Structural and functional features of central nervous system lymphatic vessels. Nature (2015) 523:337-41. doi:10.1038/nature14432

4. Engelhardt B, Carare RO, Bechmann I, Flugel A, Laman JD, Weller RO. Vascular, glial, and lymphatic immune gateways of the central nervous system. Acta Neuropathol (2016) 132:317-38. doi:10.1007/s00401-016-1606-5

5. Louveau A, Harris TH, Kipnis J. Revisiting the mechanisms of CNS immune privilege. Trends Immunol (2015) 36:569-77. doi:10.1016/j.it.2015.08.006

6. Mohammad MG, Tsai VW, Ruitenberg MJ, Hassanpour M, Li H, Hart PH, et al. Immune cell trafficking from the brain maintains CNS immune tolerance. J Clin Invest (2014) 124:1228-41. doi:10.1172/JCI71544

7. Andres KH, von During M, Muszynski K, Schmidt RF. Nerve fibres and their terminals of the dura mater encephali of the rat. Anat Embryol (Berl) (1987) 175:289-301. doi:10.1007/BF00309843

8. Yang L, Kress BT, Weber HJ, Thiyagarajan M, Wang B, Deane R, et al. Evaluating glymphatic pathway function utilizing clinically relevant intrathecal infusion of CSF tracer. J Transl Med (2013) 11:107. doi:10.1186/1479-5876-11-107

9. Aspelund A, Antila S, Proulx ST, Karlsen TV, Karaman S, Detmar M, et al. A dural lymphatic vascular system that drains brain interstitial fluid and macromolecules. J Exp Med (2015) 212:991-9. doi:10.1084/jem.20142290

10. Ma ZM, Dutra J, Fritts L, Miller CJ. Lymphatic dissemination of simian immunodeficiency virus after penile inoculation. J Virol (2016) 90:4093-104. doi:10.1128/JVI.02947-15

11. Liu YJ, Grouard G, de Bouteiller O, Banchereau J. Follicular dendritic cells and germinal centers. Int Rev Cytol (1996) 166:139-79. doi:10.1016/ S0074-7696(08)62508-5

12. Aguzzi A, Kranich J, Krautler NJ. Follicular dendritic cells: origin, phenotype, and function in health and disease. Trends Immunol (2014) 35:105-13. doi:10.1016/j.it.2013.11.001

13. Matsumoto M, Fu YX, Molina H, Chaplin DD. Lymphotoxin-alpha-deficient and TNF receptor-I-deficient mice define developmental and functional characteristics of germinal centers. Immunol Rev (1997) 156:137-44. doi:10.1111/ j.1600-065X.1997.tb00965.x

14. MacLennan IC. Germinal centers. Annu Rev Immunol (1994) 12:117-39. doi:10.1146/annurev.iy.12.040194.001001

15. Allen CD, Cyster JG. Follicular dendritic cell networks of primary follicles and germinal centers: phenotype and function. Semin Immunol (2008) 20:14-25. doi:10.1016/j.smim.2007.12.001

16. Heesters BA, Myers RC, Carroll MC. Follicular dendritic cells: dynamic antigen libraries. Nat Rev Immunol (2014) 14:495-504. doi:10.1038/nri3689

17. Burton GF, Keele BF, Estes JD, Thacker TC, Gartner S. Follicular dendritic cell contributions to HIV pathogenesis. Semin Immunol (2002) 14:275-84. doi:10.1016/S1044-5323(02)00060-X

18. Schrager LK, D'Souza MP. Cellular and anatomical reservoirs of HIV-1 in patients receiving potent antiretroviral combination therapy. JAMA (1998) 280:67-71. doi:10.1001/jama.280.1.67

19. Cavert W, Notermans DW, Staskus K, Wietgrefe SW, Zupancic M, Gebhard K, et al. Kinetics of response in lymphoid tissues to antiretroviral therapy of HIV-1 infection. Science (1997) 276:960-4. doi:10.1126/science.276.5314.960

20. Schacker T, Little S, Connick E, Gebhard-Mitchell K, Zhang ZQ, Krieger J, et al. Rapid accumulation of human immunodeficiency virus (HIV) in

\section{FUNDING}

Authors would like to acknowledge NINDS R01 NS097147 to PJ and NIAID R01 AI113883; AI129745; DA043164; and R21MH11345501 to SB. We would also like to thank Robin Taylor for assistance with illustrations.

lymphatic tissue reservoirs during acute and early HIV infection: implications for timing of antiretroviral therapy. J Infect Dis (2000) 181:354-7. doi: $10.1086 / 315178$

21. Zhang J, Perelson AS. Contribution of follicular dendritic cells to persistent HIV viremia. J Virol (2013) 87:7893-901. doi:10.1128/JVI.00556-13

22. Rothenberger MK, Keele BF, Wietgrefe SW, Fletcher CV, Beilman GJ, Chipman JG, et al. Large number of rebounding/founder HIV variants emerge from multifocal infection in lymphatic tissues after treatment interruption. Proc Natl Acad Sci U S A (2015) 112:E1126-34. doi:10.1073/ pnas. 1414926112

23. Keele BF, Tazi L, Gartner S, Liu Y, Burgon TB, Estes JD, et al. Characterization of the follicular dendritic cell reservoir of human immunodeficiency virus type 1. J Virol (2008) 82:5548-61. doi:10.1128/JVI.00124-08

24. Dave RS, Sharma RK, Muir RR, Haddad E, Gumber S, Villinger F, et al. FDC:TFH interactions within cervical lymph nodes of SIV-infected Rhesus macaques. J Neuroimmune Pharmacol (2017). doi:10.1007/s11481-0179775-0

25. McGary CS, Deleage C, Harper J, Micci L, Ribeiro SP, Paganini S, et al. CTLA-4+PD-1- memory CD4+ T cells critically contribute to viral persistence in antiretroviral therapy-suppressed, SIV-infected Rhesus macaques. Immunity (2017) 47(776-788):e5. doi:10.1016/j.immuni.2017.09.018

26. Ayala VI, Deleage C, Trivett MT, Jain S, Coren LV, Breed MW, et al. CXCR5dependent entry of CD8 T Cells into Rhesus macaque B-cell follicles achieved through T-cell engineering. J Virol (2017) 91. doi:10.1128/JVI.02507-16

27. Leong YA, Chen Y, Ong HS, Wu D, Man K, Deleage C, et al. CXCR5(+) follicular cytotoxic T cells control viral infection in B cell follicles. Nat Immunol (2016) 17:1187-96. doi:10.1038/ni.3543

28. Miles B, Connick E. TFH in HIV latency and as sources of replicationcompetent virus. Trends Microbiol (2016) 24:338-44. doi:10.1016/j.tim.2016. 02.006

29. Sabri F, Prados A, Munoz-Fernandez R, Lantto R, Fernandez-Rubio P, Nasi A, et al. Impaired B cells survival upon production of inflammatory cytokines by HIV-1 exposed follicular dendritic cells. Retrovirology (2016) 13:61. doi:10.1186/s12977-016-0295-4

30. Deleage C, Wietgrefe SW, Del Prete G, Morcock DR, Hao XP, Piatak M Jr, et al. Defining HIV and SIV reservoirs in lymphoid tissues. Pathog Immun (2016) 1:68-106. doi:10.20411/pai.v1i1.100

31. Fukazawa Y, Lum R, Okoye AA, Park H, Matsuda K, Bae JY, et al. B cell follicle sanctuary permits persistent productive simian immunodeficiency virus infection in elite controllers. Nat Med (2015) 21:132-9. doi:10.1038/ $\mathrm{nm} .3781$

32. Jain PN, Hollenbach A, Sagar R, Callen D, Yao S, Buch H, et al. Trafficking of conventional dendritic cells into the central nervous system in response to SIV and morphine creating viral reservoir in follicular DC within cervical lymph nodes of Rhesus macaques (VIR9P.1146). J Immunol (2015) 194(1):215.12.

33. Xu H, Wang X, Malam N, Aye PP, Alvarez X, Lackner AA, et al. Persistent simian immunodeficiency virus infection drives differentiation, aberrant accumulation, and latent infection of germinal center follicular T helper cells. J Virol (2015) 90:1578-87. doi:10.1128/JVI.02471-15

34. Fletcher CV, Staskus K, Wietgrefe SW, Rothenberger M, Reilly C, Chipman JG, et al. Persistent HIV-1 replication is associated with lower antiretroviral drug concentrations in lymphatic tissues. Proc Natl Acad Sci U S A (2014) 111:2307-12. doi:10.1073/pnas.1318249111

35. Thacker TC, Zhou X, Estes JD, Jiang Y, Keele BF, Elton TS, et al. Follicular dendritic cells and human immunodeficiency virus type 1 transcription in CD4+ T cells. J Virol (2009) 83:150-8. doi:10.1128/JVI.01652-08

36. Ho J, Moir S, Kulik L, Malaspina A, Donoghue ET, Miller NJ, et al. Role for CD21 in the establishment of an extracellular HIV reservoir in lymphoid tissues. J Immunol (2007) 178:6968-74. doi:10.4049/jimmunol.178.11.6968 
37. Li Q, Lifson JD, Duan L, Schacker TW, Reilly C, Carlis J, et al. Potential roles of follicular dendritic cell-associated osteopontin in lymphoid follicle pathology and repair and in B cell regulation in HIV-1 and SIV infection. J Infect Dis (2005) 192:1269-76. doi:10.1086/444430

38. Smith-Franklin BA, Keele BF, Tew JG, Gartner S, Szakal AK, Estes JD, et al. Follicular dendritic cells and the persistence of HIV infectivity: the role of antibodies and Fcgamma receptors. J Immunol (2002) 168:2408-14. doi:10.4049/jimmunol.168.5.2408

39. Estes JD, Keele BF, Tenner-Racz K, Racz P, Redd MA, Thacker TC, et al. Follicular dendritic cell-mediated up-regulation of CXCR4 expression on CD4 T cells and HIV pathogenesis. J Immunol (2002) 169:2313-22. doi:10.4049/ jimmunol.169.5.2313

40. Moir S, Malaspina A, Li Y, Chun TW, Lowe T, Adelsberger J, et al. B cells of HIV-1-infected patients bind virions through CD21-complement interactions and transmit infectious virus to activated T cells. J Exp Med (2000) 192:637-46. doi:10.1084/jem.192.5.637

41. Davis LE, Hjelle BL, Miller VE, Palmer DL, Llewellyn AL, Merlin TL, et al. Early viral brain invasion in iatrogenic human immunodeficiency virus infection. Neurology (1992) 42:1736-9. doi:10.1212/WNL.42.9.1736

42. Gonzalez-Scarano F, Martin-Garcia J. The neuropathogenesis of AIDS. Nat Rev Immunol (2005) 5:69-81. doi:10.1038/nri1527

43. Williams DW, Veenstra M, Gaskill PJ, Morgello S, Calderon TM, Berman JW. Monocytes mediate HIV neuropathogenesis: mechanisms that contribute to HIV associated neurocognitive disorders. Curr HIV Res (2014) 12:85-96. doi:10.2174/1570162X12666140526114526

44. Brenchley JM, Schacker TW, Ruff LE, Price DA, Taylor JH, Beilman GJ, et al. CD4+ T cell depletion during all stages of HIV disease occurs predominantly in the gastrointestinal tract. JExp Med (2004) 200:749-59. doi:10.1084/ jem. 20040874

45. Nath A, Sacktor N. Influence of highly active antiretroviral therapy on persistence of HIV in the central nervous system. Curr Opin Neurol (2006) 19:358-61. doi:10.1097/01.wco.0000236614.51592.ca

46. Iordanskiy S, Kashanchi F. Potential of radiation-induced cellular stress for reactivation of latent HIV-1 and killing of infected cells. AIDS Res Hum Retroviruses (2016) 32:120-4. doi:10.1089/AID.2016.0006

47. Limsirichai P, Gaj T, Schaffer DV. CRISPR-mediated activation of latent HIV-1 expression. Mol Ther (2016) 24:499-507. doi:10.1038/mt.2015.213

48. van der Sluis RM, van Capel TM, Speijer D, Sanders RW, Berkhout B, de Jong EC, et al. Dendritic cell type-specific HIV-1 activation in effector T cells: implications for latent HIV-1 reservoir establishment. AIDS (2015) 29:1003-14. doi:10.1097/QAD.0000000000000637

49. Mohammadi P, Ciuffi A, Beerenwinkel N. Dynamic models of viral replication and latency. Curr Opin HIV AIDS (2015) 10:90-5. doi:10.1097/ COH.0000000000000136

50. Licht A, Alter G. A drug-free zone-lymph nodes as a safe haven for HIV. Cell Host Microbe (2016) 19:275-6. doi:10.1016/j.chom.2016.02.018

51. Lorenzo-Redondo R, Fryer HR, Bedford T, Kim EY, Archer J, Kosakovsky Pond SL, et al. Persistent HIV-1 replication maintains the tissue reservoir during therapy. Nature (2016) 530:51-6. doi:10.1038/nature16933

52. Pallikkuth S, Sharkey M, Babic DZ, Gupta S, Stone GW, Fischl MA, et al. Peripheral T follicular helper cells are the major HIV reservoir within central memory CD4 $\mathrm{T}$ cells in peripheral blood from chronically HIV-infected individuals on combination antiretroviral therapy. J Virol (2015) 90:2718-28. doi:10.1128/JVI.02883-15

53. Costiniuk CT, Jenabian MA. HIV reservoir dynamics in the face of highly active antiretroviral therapy. AIDS Patient Care STDS (2015) 29:55-68. doi:10.1089/apc.2014.0173

54. Smith BA, Gartner S, Liu Y, Perelson AS, Stilianakis NI, Keele BF, et al. Persistence of infectious HIV on follicular dendritic cells. J Immunol (2001) 166:690-6. doi:10.4049/jimmunol.166.1.690

55. Chomont N, El-Far M, Ancuta P, Trautmann L, Procopio FA, Yassine-Diab B, et al. HIV reservoir size and persistence are driven by $\mathrm{T}$ cell survival and homeostatic proliferation. Nat Med (2009) 15:893-900. doi:10.1038/ nm. 1972

56. Haase AT, Henry K, Zupancic M, Sedgewick G, Faust RA, Melroe H, et al. Quantitative image analysis of HIV-1 infection in lymphoid tissue. Science (1996) 274:985-9. doi:10.1126/science.274.5289.985

57. Hong JJ, Silveira E, Amancha PK, Byrareddy SN, Gumber S, Chang KT, et al. Early initiation of antiretroviral treatment postSIV infection does not resolve lymphoid tissue activation. AIDS (2017) 31:1819-24. doi:10.1097/ QAD.0000000000001576

58. Santangelo PJ, Rogers KA, Zurla C, Blanchard EL, Gumber S, Strait K, et al. Whole-body immunoPET reveals active SIV dynamics in viremic and antiretroviral therapy-treated macaques. Nat Methods (2015) 12:427-32. doi:10.1038/nmeth.3320

59. Martinot AJ, Meythaler M, Pozzi LA, Dalecki Boisvert K, Knight H, Walsh D, et al. Acute SIV infection in sooty mangabey monkeys is characterized by rapid virus clearance from lymph nodes and absence of productive infection in germinal centers. PLoS One (2013) 8:e57785. doi:10.1371/journal. pone. 0057785

60. Kepler TB, Perelson AS. Cyclic re-entry of germinal center B cells and the efficiency of affinity maturation. Immunol Today (1993) 14:412-5. doi:10.1016/0167-5699(93)90145-B

61. Heesters BA, Chatterjee P, Kim YA, Gonzalez SF, Kuligowski MP, Kirchhausen T, et al. Endocytosis and recycling of immune complexes by follicular dendritic cells enhances B cell antigen binding and activation. Immunity (2013) 38:1164-75. doi:10.1016/j.immuni.2013.02.023

62. Grouard G, Durand I, Filgueira L, Banchereau J, Liu YJ. Dendritic cells capable of stimulating T cells in germinal centres. Nature (1996) 384:364-7. doi: $10.1038 / 384364 \mathrm{a} 0$

63. Aguzzi A, Krautler NJ. Characterizing follicular dendritic cells: a progress report. Eur J Immunol (2010) 40:2134-8. doi:10.1002/eji.201040765

64. Chao C, Jacobson LP, Tashkin D, Martinez-Maza O, Roth MD, Margolick JB, et al. Recreational drug use and T lymphocyte subpopulations in HIVuninfected and HIV-infected men. Drug Alcohol Depend (2008) 94:165-71. doi:10.1016/j.drugalcdep.2007.11.010

65. Fletcher AL, Acton SE, Knoblich K. Lymph node fibroblastic reticular cells in health and disease. Nat Rev Immunol (2015) 15:350-61. doi:10.1038/nri3846

66. Sagar D, Lamontagne A, Foss CA, Khan ZK, Pomper MG, Jain P. Dendritic cell CNS recruitment correlates with disease severity in EAE via CCL2 chemotaxis at the blood-brain barrier through paracellular transmigration and ERK activation. J Neuroinflammation (2012) 9:245. doi:10.1186/17422094-9-245

67. Jain P, Coisne C, Enzmann G, Rottapel R, Engelhardt B. Alpha4betal integrin mediates the recruitment of immature dendritic cells across the blood-brain barrier during experimental autoimmune encephalomyelitis. J Immunol (2010) 184:7196-206. doi:10.4049/jimmunol.0901404

68. Serafini B, Columba-Cabezas S, Di Rosa F, Aloisi F. Intracerebral recruitment and maturation of dendritic cells in the onset and progression of experimental autoimmune encephalomyelitis. Am J Pathol (2000) 157:1991-2002. doi:10.1016/S0002-9440(10)64838-9

69. Zozulya AL, Ortler S, Lee J, Weidenfeller C, Sandor M, Wiendl H, et al. Intracerebral dendritic cells critically modulate encephalitogenic versus regulatory immune responses in the CNS. J Neurosci (2009) 29:140-52. doi:10.1523/JNEUROSCI.2199-08.2009

70. Pashenkov M, Huang YM, Kostulas V, Haglund M, Soderstrom M, Link H. Two subsets of dendritic cells are present in human cerebrospinal fluid. Brain (2001) 124:480-92. doi:10.1093/brain/124.3.480

71. Matyszak MK, Perry VH. The potential role of dendritic cells in immunemediated inflammatory diseases in the central nervous system. Neuroscience (1996) 74:599-608. doi:10.1016/0306-4522(96)00160-1

72. Hatterer E, Touret M, Belin MF, Honnorat J, Nataf S. Cerebrospinal fluid dendritic cells infiltrate the brain parenchyma and target the cervical lymph nodes under neuroinflammatory conditions. PLoS One (2008) 3:e3321. doi:10.1371/journal.pone.0003321

73. Sagar D, Foss C, El Baz R, Pomper MG, Khan ZK, Jain P. Mechanisms of dendritic cell trafficking across the blood-brain barrier. J Neuroimmune Pharmacol (2012) 7:74-94. doi:10.1007/s11481-011-9302-7

74. Hollenbach R, Sagar D, Khan ZK, Callen S, Yao H, Shirazi J, et al. Effect of morphine and SIV on dendritic cell trafficking into the central nervous system of Rhesus macaques. J Neurovirol (2014) 20:175-83. doi:10.1007/ s13365-013-0182-x

75. Kairouz S, Hashash J, Kabbara W, McHayleh W, Tabbara IA. Dendritic cell neoplasms: an overview. Am J Hematol (2007) 82:924-8. doi:10.1002/ ajh. 20857

76. Louveau A, Smirnov I, Keyes TJ, Eccles JD, Rouhani SJ, Peske JD, et al. Corrigendum: structural and functional features of central nervous system lymphatic vessels. Nature (2016) 533(7602):278. doi:10.1038/nature16999 
77. Bradstreet JJ, Ruggiero M, Pacini S. Commentary: structural and functional features of central nervous system lymphatic vessels. Front Neurosci (2015) 9:485. doi:10.3389/fnins.2015.00485

78. van Zwam M, Huizinga R, Melief MJ, Wierenga-Wolf AF, van Meurs M, Voerman JS, et al. Brain antigens in functionally distinct antigen-presenting cell populations in cervical lymph nodes in MS and EAE. J Mol Med (2009) 87:273-86. doi:10.1007/s00109-008-0421-4

79. Zhou X, Shapiro L, Fellingham G, Willardson BM, Burton GF. HIV replication in CD4+ $\mathrm{T}$ lymphocytes in the presence and absence of follicular dendritic cells: inhibition of replication mediated by alpha-1-antitrypsin through altered IkappaBalpha ubiquitination. J Immunol (2011) 186:3148-55. doi:10.4049/jimmunol.1001358

80. Spiegel H, Herbst H, Niedobitek G, Foss HD, Stein H. Follicular dendritic cells are a major reservoir for human immunodeficiency virus type 1 in lymphoid tissues facilitating infection of CD4+ T-helper cells. Am J Pathol (1992) 140:15-22.

81. Stahmer I, Zimmer JP, Ernst M, Fenner T, Finnern R, Schmitz H, et al. Isolation of normal human follicular dendritic cells and CD4-independent in vitro infection by human immunodeficiency virus (HIV-1). Eur J Immunol (1991) 21:1873-8. doi:10.1002/eji.1830210814

82. Dimopoulos Y, Moysi E, Petrovas C. The lymph node in HIV pathogenesis. Curr HIV/AIDS Rep (2017) 14(4):133-40. doi:10.1007/s11904-017-0359-7

83. Connick E, Mattila T, Folkvord JM, Schlichtemeier R, Meditz AL, Ray MG, et al. CTL fail to accumulate at sites of HIV-1 replication in lymphoid tissue. J Immunol (2007) 178:6975-83. doi:10.4049/jimmunol.178.11.6975

84. Li S, Folkvord JM, Rakasz EG, Abdelaal HM, Wagstaff RK, Kovacs KJ, et al. Simian immunodeficiency virus-producing cells in follicles are partially suppressed by CD8+ cells in vivo. J Virol (2016) 90:11168-80. doi:10.1128/ JVI.01332-16

85. Rezk SA, Nathwani BN, Zhao X, Weiss LM. Follicular dendritic cells: origin, function, and different disease-associated patterns. Hum Pathol (2013) 44:937-50. doi:10.1016/j.humpath.2012.10.005

86. El Shikh ME, Pitzalis C. Follicular dendritic cells in health and disease. Front Immunol (2012) 3:292. doi:10.3389/fimmu.2012.00292

87. Chahroudi A, Silvestri G. HIV and Tfh cells: circulating new ideas to identify and protect. Immunity (2016) 44:16-8. doi:10.1016/j.immuni.2015. 12.016

88. Yamamoto T, Lynch RM, Gautam R, Matus-Nicodemos R, Schmidt SD, Boswell KL, et al. Quality and quantity of TFH cells are critical for broad antibody development in SHIVAD8 infection. Sci Transl Med (2015) 7:298ra120. doi:10.1126/scitranslmed.aab3964

89. Petrovas C, Yamamoto T, Gerner MY, Boswell KL, Wloka K, Smith EC, et al. CD4 $\mathrm{T}$ follicular helper cell dynamics during SIV infection. J Clin Invest (2012) 122:3281-94. doi:10.1172/JCI63039

90. Havenar-Daughton C, Reiss SM, Carnathan DG, Wu JE, Kendric K, Torrents de la Pena A, et al. Cytokine-independent detection of antigen-specific germinal center $\mathrm{T}$ follicular helper cells in immunized nonhuman primates using a live cell activation-induced marker technique. J Immunol (2016) 197:994-1002. doi:10.4049/jimmunol.1600320

91. Zaunders J, Xu Y, Kent SJ, Koelsch KK, Kelleher AD. Divergent expression of CXCR5 and CCR5 on CD4+ T cells and the paradoxical accumulation of T follicular helper cells during HIV infection. Front Immunol (2017) 8:495. doi:10.3389/fimmu.2017.00495

92. Xu Y, Weatherall C, Bailey M, Alcantara S, De Rose R, Estaquier J, et al. Simian immunodeficiency virus infects follicular helper CD4 T cells in lymphoid tissues during pathogenic infection of pigtail macaques. J Virol (2013) 87:3760-73. doi:10.1128/JVI.02497-12

93. Xu Y, Phetsouphanh C, Suzuki K, Aggrawal A, Graff-Dubois S, Roche M, et al. HIV-1 and SIV predominantly use CCR5 expressed on a precursor population to establish infection in T follicular helper cells. Front Immunol (2017) 8:376. doi:10.3389/fimmu.2017.00376

94. Graff-Dubois S, Rouers A, Moris A. Impact of chronic HIV/SIV infection on $\mathrm{T}$ follicular helper cell subsets and germinal center homeostasis. Front Immunol (2016) 7:501. doi:10.3389/fimmu.2016.00501

95. Hey-Nguyen WJ, Xu Y, Pearson CF, Bailey M, Suzuki K, Tantau R, et al. Quantification of residual germinal center activity and HIV-1 DNA and RNA levels using fine needle biopsies of lymph nodes during antiretroviral therapy. AIDS Res Hum Retroviruses (2017) 33:648-57. doi:10.1089/aid. 2016.0171
96. Gonzalez-Figueroa P, Roco JA, Vinuesa CG. Germinal center lymphocyte ratios and successful HIV vaccines. Trends Mol Med (2017) 23:95-7. doi:10.1016/j.molmed.2016.12.009

97. Miles B, Miller SM, Folkvord JM, Kimball A, Chamanian M, Meditz AL, et al. Follicular regulatory T cells impair follicular T helper cells in HIV and SIV infection. Nat Commun (2015) 6:8608. doi:10.1038/ncomms9608

98. Chowdhury A, Del Rio Estrada PM, Tharp GK, Trible RP, Amara RR, Chahroudi A, et al. Decreased T follicular regulatory cell/T follicular helper cell (TFH) in simian immunodeficiency virus-infected Rhesus macaques may contribute to accumulation of TFH in chronic infection. J Immunol (2015) 195:3237-47. doi:10.4049/jimmunol.1402701

99. Miller SM, Miles B, Guo K, Folkvord J, Meditz AL, McCarter MD, et al. Follicular regulatory $\mathrm{T}$ cells are highly permissive to R5-tropic HIV-1.J Virol (2017) 91(17):e00430-17. doi:10.1128/JVI.00430-17

100. Huot N, Jacquelin B, Garcia-Tellez T, Rascle P, Ploquin MJ, Madec Y, et al. Natural killer cells migrate into and control simian immunodeficiency virus replication in lymph node follicles in African green monkeys. Nat Med (2017) 23:1277-86. doi:10.1038/nm.4421

101. Mylvaganam GH, Rios D, Abdelaal HM, Iyer S, Tharp G, Mavinger M, et al. Dynamics of SIV-specific CXCR5+ CD8 T cells during chronic SIV infection. Proc Natl Acad Sci U S A (2017) 114:1976-81. doi:10.1073/pnas.1621418114

102. Heesters BA, Lindqvist M, Vagefi PA, Scully EP, Schildberg FA, Altfeld M, et al. Follicular dendritic cells retain infectious HIV in cycling endosomes. PLoS Pathog (2015) 11:e1005285. doi:10.1371/journal.ppat.1005285

103. Luzuriaga K, Tabak B, Garber M, Chen YH, Ziemniak C, McManus MM, et al. HIV type 1 (HIV-1) proviral reservoirs decay continuously under sustained virologic control in HIV-1-infected children who received early treatment. J Infect Dis (2014) 210:1529-38. doi:10.1093/infdis/jiu297

104. Passaes CP, Saez-Cirion A. HIV cure research: advances and prospects. Virology (2014) 45(4-455):340-52. doi:10.1016/j.virol.2014.02.021

105. Smith CJ, Phillips AN, Dauer B, Johnson MA, Lampe FC, Youle MS, et al. Factors associated with viral rebound among highly treatment-experienced HIV-positive patients who have achieved viral suppression. HIV Med (2009) 10:19-27. doi:10.1111/j.1468-1293.2008.00650.x

106. Reekie J, Mocroft A, Ledergerber B, Beniowski M, Clotet B, van Lunzen J, et al. History of viral suppression on combination antiretroviral therapy as a predictor of virological failure after a treatment change. HIV Med (2010) 11:469-78. doi:10.1111/j.1468-1293.2009.00816.x

107. Allers K, Hutter G, Hofmann J, Loddenkemper C, Rieger K, Thiel E, et al. Evidence for the cure of HIV infection by CCR5Delta32/Delta32 stem cell transplantation. Blood (2011) 117:2791-9. doi:10.1182/blood2010-09-309591

108. Byrareddy SN, Arthos J, Cicala C, Villinger F, Ortiz KT, Little D, et al. Sustained virologic control in SIV+ macaques after antiretroviral and alpha4beta7 antibody therapy. Science (2016) 354:197-202. doi:10.1126/science. aag 1276

109. Zhang Y, Yin C, Zhang T, Li F, Yang W, Kaminski R, et al. CRISPR/gRNAdirected synergistic activation mediator (SAM) induces specific, persistent and robust reactivation of the HIV-1 latent reservoirs. Sci Rep (2015) 5:16277. doi:10.1038/srep16277

110. Kaminski R, Chen Y, Fischer T, Tedaldi E, Napoli A, Zhang Y, et al. Elimination of HIV-1 genomes from human T-lymphoid cells by CRISPR/ Cas9 gene editing. Sci Rep (2016) 6:22555. doi:10.1038/srep22555

111. Yin C, Zhang T, Qu X, Zhang Y, Putatunda R, Xiao X, et al. In vivo excision of HIV-1 provirus by saCas 9 and multiplex single-guide RNAs in animal models. Mol Ther (2017) 25:1168-86. doi:10.1016/j.ymthe.2017.03.012

Conflict of Interest Statement: The authors declare that the research was conducted in the absence of any commercial or financial relationships that could be construed as a potential conflict of interest.

The reviewer SB and handling Editor declared their shared affiliation.

Copyright (c) 2018 Dave, Jain and Byrareddy. This is an open-access article distributed under the terms of the Creative Commons Attribution License (CC BY). The use, distribution or reproduction in other forums is permitted, provided the original author(s) and the copyright owner are credited and that the original publication in this journal is cited, in accordance with accepted academic practice. No use, distribution or reproduction is permitted which does not comply with these terms. 